\title{
Data report: consolidation and permeability of sediments from Sites C0011, C0012, and C0018, IODP Expeditions 322 and 333, NanTroSEIZE Stage 2'
}

Junhua $\mathrm{Guo}^{2}$ and Michael B. Underwood ${ }^{2}$

\section{Chapter contents}

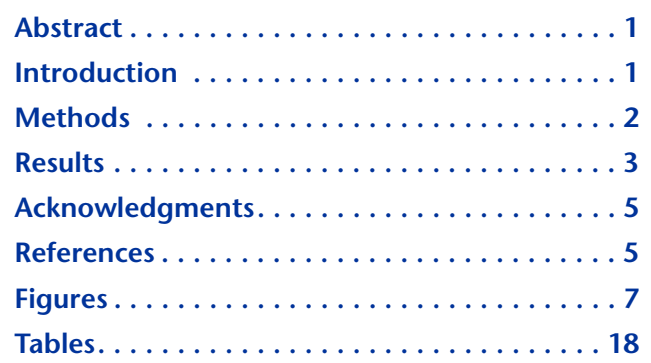

${ }^{1}$ Guo, J., and Underwood, M.B., 2014. Data report: consolidation and permeability of sediments from Sites C0011, C0012, and C0018, IODP Expeditions 322 and 333, NanTroSEIZE Stage 2. In Saito, S., Underwood, M.B., Kubo, Y., and the Expedition 322 Scientists, Proc. IODP, 322: Tokyo (Integrated Ocean Drilling Program Management International, Inc.).

doi:10.2204/iodp.proc.322.209.2014

${ }^{2}$ Department of Geological Sciences, University of Missouri, 101 Geology Building, Columbia MO 65211, USA. Correspondence author: underwoodm@missouri.edu

\section{Abstract}

This report documents the results of constant-rate-of-strain consolidation tests on mud and mudstone samples from the Kumano transect of the Nankai subduction margin. The coring sites include Integrated Ocean Drilling Program Sites C0011 and C0012 in the Shikoku Basin (subduction inputs) and Site C0018 in a small basin on the landward trench slope. Samples from Sites C0011 and C0012 yielded compression indexes of 0.31 to 2.70 (average $=0.99$ ); values generally decrease with increasing depth. Values of in situ intrinsic permeability at Site C0012 range from $3.03 \times 10^{-15} \mathrm{~m}^{2}$ to $3.65 \times 10^{-19} \mathrm{~m}^{2}$ and decrease erratically with depth. Comparable values at Site C0011 decrease steadily with depth and range from $1.17 \times 10^{-16} \mathrm{~m}^{2}$ to $1.57 \times 10^{-19} \mathrm{~m}^{2}$. At both sites, overconsolidation ratios (maximum past effective normal stress to computed values of in situ hydrostatic vertical effective stress at equivalent depths) are indicative of apparent overconsolidation. At Site C0018, values of compression index range from 0.42 to 0.60 (average $=0.53$ ), with no obvious trend as a function of burial depth. Values of in situ intrinsic permeability decrease with depth from $3.33 \times 10^{-16} \mathrm{~m}^{2}$ to $1.47 \times 10^{-17} \mathrm{~m}^{2}$, and the overconsolidation ratio varies from 0.76 to 1.82 , indicating that the specimens are slightly underconsolidated to moderately overconsolidated.

\section{Introduction}

The Nankai Trough Seismogenic Experiment (NanTroSEIZE) is a multistage drilling project that was implemented to understand the mechanics of subduction zone faulting and earthquakes offshore southwest Japan (Tobin and Kinoshita, 2007). The so-called Kumano transect extends from the Kumano Basin, offshore the Kii Peninsula, across the Nankai accretionary prism and into the Shikoku Basin (Fig. F1). This report focuses on three NanTroSEIZE sites that were drilled during Integrated Ocean Drilling Program (IODP) Expeditions 322 and 333 (see the "Site C0011" and "Site C0012" chapters [Expedition 322 Scientists, 2010a, 2010b] and the "Site C0011," "Site C0012," and "Site C0018" chapters [Expedition 333 Scientists, 2012a, 2012b, 2012c]). Site C0011 is located on the northwest flank of a prominent bathymetric high in the Shikoku Basin (Kashinosaki Knoll), whereas Site C0012 is located near the crest of the knoll. Those sites were drilled to document 
how deposition of the subduction inputs varied as a function of basement topography. Site C0018 is positioned within a small basin on the lower trench slope. That site was cored to study the history of mass transport deposits and the links between sedimentation and fault displacement within the accretionary prism.

We completed constant-rate-of-strain consolidation (CRSC) tests on 33 whole-round samples of mud and mudstone. The purposes of these tests were to quantify sediment compression properties, determine maximum values of in situ effective normal stress, and estimate intrinsic permeability and hydraulic conductivity. The results provide insights into subseafloor fluid flow, consolidation, and dewatering history, as well as the potential for generation of excess pore pressure across a range of depositional environments and facies. The data become more significant when comparisons are made with complementary test results from other sites along the Kumano transect (Dugan and Daigle, 2011; Guo et al., 2011; Saffer et al., 2011).

\section{Methods}

\section{Sampling}

We tested 27 whole-round samples of mud and mudstone from Sites C0011 and C00012 in the Shikoku Basin (Table T1). Their distributions by depth and lithostratigraphic unit are shown in Figure F2, as are bedding dips from intervals in close proximity. Six samples from Site C0018 were also tested, four from a mud-rich slope-basin facies and two from a sandrich facies. The whole-round samples were cut onboard the D/V Chikyu within several hours of recovery, capped and taped, sealed with wet sponges in aluminum vacuum bags, and maintained at $\sim 4^{\circ} \mathrm{C}$ during shipment and storage to prevent moisture loss. Immediately prior to laboratory testing, the samples were extruded from the core liners and a trimming jig was used to shape cylindrical specimens.

\section{Moisture and density}

After trimming each cylinder of mudstone for a CRSC test, we retained two or three pieces of trimmings to measure water content by oven drying to constant mass at $105^{\circ} \mathrm{C}$ (ASTM, 2006). The value of water content is equal to the difference in weight before and after oven drying divided by the oven-dried weight (Blum, 1997; Expedition 316 Scientists, 2009). The calculated values of void ratio (e) include a correction for salt in the pore water. Those values can be compared to shipboard data from nearby sample intervals to assess sample disturbance and/or loss of moisture during shipment and storage. In some instances, shore-based $e$ values are greater than shipboard $e$ values; the higher values can be attributed to drilling/coring disturbance (e.g., dilation of microfractures) or subtle differences in the mudstone's mineral composition and/or texture between the adjacent intervals. Deformation of the core was particularly acute during Expedition 322 with use of the rotary core barrel system.

\section{Consolidation tests}

CRSC tests were conducted at the University of Missouri (USA) in the oedometer system described by Guo et al. (2011), following the protocols and configurations specified by the American Society for Testing and Materials (ASTM, 2006). According to these procedures, each cylinder of sediment is placed in a stainless steel specimen ring (diameter $=4.14$ $\mathrm{cm})$ to maintain a condition of zero lateral strain. The consolidation cell and lines are then evacuated of air using a vacuum pump. The specimen is backpressured to $\sim 200-400 \mathrm{kPa}$ using de-aired synthetic seawater $(1.75 \mathrm{~g} \mathrm{NaCl}$ in $500 \mathrm{~mL}$ distilled water) for $24 \mathrm{~h}$ to ensure saturation and to dissolve any air remaining in the system lines. During backpressuring, the axial load actuator maintains height with a strain of $0.2 \%$. Constant-rate-of-strain loading is applied using a computer-controlled load frame, with the sample base undrained and sample top open to the backpressure. The sample height, the applied vertical total stress, and the basal pore pressure are constantly monitored. The maximum axial load of our loading frame is $44 \mathrm{kN}$; for specimens with a diameter of $4.14 \mathrm{~cm}$, that load corresponds to a maximum vertical total stress of $33 \mathrm{MPa}$. With the backpressure ranging from 200 to $400 \mathrm{kPa}$, the maximum vertical effective stress ranges from approximately 32 to $33 \mathrm{MPa}$. For each test, the rate of displacement (or strain rate) is specified in order to keep the anticipated ratio of basal excess pore pressure to total axial stress below 0.10. Displacements are measured by a linear variable differential transformer (LVDT) mounted at the top of the consolidation cell, and the displacements are corrected after ASTM (2006) to account for the compliance of the testing system. The resulting strain rates are documented in Table T2.

As documented previously by Guo et al. (2011), the following equations (ASTM, 2006; Long et al., 2008) were used to compute values of axial strain $(\varepsilon)$, base excess pressure $(\Delta u)$, average effective axial stress 
$\left(\sigma_{\mathrm{v}}^{\prime}\right)$, hydraulic conductivity $(K)$, intrinsic permeability $(k)$, the coefficient of volume compressibility $\left(m_{\mathrm{v}}\right)$, and the coefficient of consolidation $\left(c_{\mathrm{v}}\right)$ :

$$
\begin{gathered}
\varepsilon=\delta_{\mathrm{n}} / H_{0}, \\
\Delta u=u-u_{\mathrm{b}}, \\
\sigma_{\mathrm{v}}^{\prime}=\sigma_{\mathrm{v}}-(2 / 3 \times \Delta u), \\
K=\left(\mathrm{d} \varepsilon / \mathrm{dt} \times H_{0} \times \gamma_{\mathrm{w}}\right) /(2 \times \Delta u), \\
k=(K \times v) /(\rho \times \mathrm{g}), \\
m_{\mathrm{v}}=\Delta \varepsilon / \Delta \sigma_{\mathrm{v}},
\end{gathered}
$$

and

$$
c_{\mathrm{v}}=K /\left(m_{\mathrm{v}} \times \gamma_{\mathrm{w}}\right) .
$$

All of the symbols, definitions, dimensions, and units of measure for these and other equations are defined in Table T3. During a CRSC test, hydraulic conductivity values are not reliable until the axial strain distribution reaches steady state (ASTM, 2006). Conversion of each value of vertical hydraulic conductivity under laboratory conditions to vertical intrinsic permeability (Table T2) requires knowledge of permeant properties; for that, we assumed a fluid viscosity of $0.001 \mathrm{~Pa} \cdot \mathrm{s}$ for water at $20^{\circ} \mathrm{C}$ and a fluid density of $1027 \mathrm{~kg} / \mathrm{m}^{3}$. Calculations of in situ vertical hydraulic conductivity (Table T2) similarly requires knowledge of temperature-dependent changes in permeant properties within the formation; we assumed interstitial water salinity of $35 \%$ and followed the equations of El-Dessouky and Ettouny (2002) and Fofonoff (1985), as constrained by measurements of borehole temperature (Expedition 333 Scientists, 2012a, 2012b). After each test was finished, sample disturbance was evaluated by comparing the $\Delta e$ value to $e_{\mathrm{i}}$ (Lunne et al., 1997). Most of the samples rate "poor" to "very poor" using this criterion (Table T1).

For each set of test results, the compression index $\left(C_{c}\right)$ refers to the slope of the virgin portion of the $e$ versus $\log (P)$ curve (Fig. F3). The compression index is calculated using the following equation:

$$
C_{\mathrm{c}}=(\Delta e) /\left(\Delta \log \sigma_{\mathrm{v}}^{\prime}\right)
$$

Consolidation test results can also be used to define a relation between intrinsic permeability and porosity in the form: $\log k=\log k_{\mathrm{o}}+\mathrm{a} \times n$, where $\mathrm{a}$ is a constant (e.g., Neuzil, 1994). The in situ intrinsic permeability is determined by numerically fitting a regression curve through the middle of each band of test results and extrapolating along that line to the value of in situ porosity or void ratio (Long et al., 2008). The value of in situ void ratio is picked from each consolidation-test curve at the point of intersection with maximum past effective normal stress $\left(P_{c}^{\prime}\right)$ (Fig. F3). That point is also referred to as "preconsolidation stress" (e.g., Dugan and Daigle, 2011). To solve for each specimen's value of $P^{\prime}{ }_{c}$, we employed both the Casagrande (1936) method and the strain energy density (SED) method (Becker et al., 1987). In the case of one-dimensional consolidation,

$$
\mathrm{SED}=\left[\left(\sigma_{\mathrm{vL}-1}^{\prime}+\sigma_{\mathrm{vL}}^{\prime}\right) / 2\right] \times \ln \left[\left(1-\varepsilon_{\mathrm{L}-1}\right) /\left(1-\varepsilon_{\mathrm{L}}\right)\right]
$$

We also compare each $P^{\prime} \mathrm{c}$ value to the calculated value of in situ hydrostatic vertical effective stress $\left(\sigma_{v h}^{\prime}\right)$. The gradient of hydrostatic vertical effective stress at each site was calculated by subtracting the value of hydrostatic pore pressure from the overburden pressure (total normal stress). The overburden pressure was computed by integrating the shipboard values of bulk density over the depth range of drilling (Expedition 322 Scientists, 2010a, 2010b; Expedition 333 Scientists, 2012a, 2012b, 2012c). Under conditions of monotonic and uniaxial loading, a specimen's $P_{c}^{\prime}$ value should be equal to $\sigma_{v h}^{\prime}$ at each equivalent sampling depth (e.g., Holtz and Kovacs, 1981), but there are many reasons why that expectation might not hold. To quantify such departures, the overconsolidation ratio (OCR) is defined as $P^{\prime}{ }_{c} / \sigma_{\text {vh }}^{\prime}$. An OCR of unity indicates normal consolidation. Values of OCR $<1$ indicate underconsolidation, a condition that is often caused by fluid pressures greater than hydrostatic. Values of OCR $>1$ indicate overconsolidation. True overconsolidation usually results from erosional unroofing of overburden, whereas an apparent state of overconsolidation can result from lateral tectonic stresses greater than vertical effective stress or from strengthening of sediment fabric by cementation.

\section{Results}

Summaries of CRSC test results are shown in Table T2. A complete CRSC data sheet for each test can be found in Microsoft Excel format in CRSC in "Supplementary material." Also included are figures showing time series for effective axial stress and basal excess pore pressure, consolidation curves in $e$ versus $\log \left(\sigma_{\mathrm{v}}^{\prime}\right)$ and $\varepsilon$ versus $\log \left(\sigma_{\mathrm{v}}^{\prime}\right)$ formats, excess 
pore pressure ratio, coefficient of consolidation, SED, and hydraulic conductivity.

\section{Compression index}

Figures F4, F5, and F6 show all the virgin curves from consolidation tests. Values of $C_{c}$ for samples from Sites C0011 and C0012 range from 0.31 to 2.70 (average $=0.99)($ Table T2). The overall pattern is that $C_{\mathrm{c}}$ values decrease with increasing depth (Fig. F7). Samples of hemipelagic-pyroclastic facies from the upper Shikoku Basin show higher indexes (>1.0) and more scatter, whereas deeper stratigraphic units are less compressible with average values of $\sim 0.5$. The values of compression index at Site C0018 show no systematic changes with depth or stratigraphic unit (Fig. F7), ranging from 0.42 to 0.60 (average $=0.53$ ) (Table T2).

\section{Permeability}

Values of hydraulic conductivity and intrinsic permeability during laboratory tests generally decrease in log-linear trends as the vertical effective stress is progressively increased and specimens compact to lower porosity. Test results from Sites C0011 and C0012 are grouped according to lithostratigraphic unit (Fig. F8). Samples from the hemipelagic-pyroclastic facies (Unit I) yield bands of permeability values that decrease from a high of $7.6 \times 10^{-16} \mathrm{~m}^{2}$ at $n=$ $70 \%\left(\sigma_{v}^{\prime}=1 \mathrm{MPa}\right)$ to a low of $7.3 \times 10^{-19} \mathrm{~m}^{2}$ at $n=$ $41 \%\left(\sigma_{v}^{\prime}=5.6 \mathrm{MPa}\right)$. Samples from the deeper volcanic turbidite facies (Unit II) decrease in permeability from a maximum of $2.2 \times 10^{-17} \mathrm{~m}^{2}$ at $n=65 \%\left(\sigma_{\mathrm{v}}^{\prime}\right.$ $=1 \mathrm{MPa}$ ) to a minimum of $1.5 \times 10^{-19} \mathrm{~m}^{2}$ at $n=31 \%$ $\left(\sigma_{v}^{\prime}=23 \mathrm{MPa}\right)$. For older samples (Unit III and deeper), values decrease from $2.3 \times 10^{-18} \mathrm{~m}^{2}$ at $n=$ $49 \%\left(\sigma_{\mathrm{v}}^{\prime}=1.0 \mathrm{MPa}\right)$ to $3.8 \times 10^{-20} \mathrm{~m}^{2}$ at $n=21 \%\left(\sigma_{\mathrm{v}}^{\prime}=\right.$ $32 \mathrm{MPa})$.

Values of in situ intrinsic permeability calculated for Site C0012 sampling depths range from $3.0 \times 10^{-15}$ $\mathrm{m}^{2}$ to $3.6 \times 10^{-19} \mathrm{~m}^{2}$ (Table T2), consistent with the results of Screaton et al. (2013), Dugan and Zhao (2013), and Song et al. (in press). The condensed section at Site C0012 shows an erratic depth-dependent pattern with several excursions from the typical trend of progressive burial compaction (Fig. F9). Scatter is more extreme in the hemipelagic facies (e.g., at 263 meters below seafloor [mbsf]), although some of the higher values could be due to microcracks induced by drilling. Comparable results from the expanded section at Site C0011 reveal a more consistent trend in which permeability progressively decreases with depth (Fig. F9); those $k_{\mathrm{i}}$ values range from $1.2 \times 10^{-16} \mathrm{~m}^{2}$ to $1.6 \times 10^{-19} \mathrm{~m}^{2}$ (Table T2). Data from the volcanic turbidite facies display more scatter in comparison to overlying and underlying units.

For Site C0018, laboratory permeability values for the slope-basin deposits decrease from $6.4 \times 10^{-16} \mathrm{~m}^{2}$ at $n=60 \%\left(\sigma^{\prime}=0.2 \mathrm{MPa}\right)$ to $1.3 \times 10^{-18} \mathrm{~m}^{2}$ at $n=$ $25 \%\left(\sigma_{v}^{\prime}=14 \mathrm{MPa}\right)$ (Fig. F10). The calculated in situ values define a smooth trend of steadily decreasing permeability with depth, with no obvious differences between the mass transport deposits and hemipelagic deposits (Fig. F9). The values range from a high of $3.3 \times 10^{-16} \mathrm{~m}^{2}$ at $\sim 59$ mbsf to a low of $1.5 \times$ $10^{-17} \mathrm{~m}^{2}$ at $\sim 311 \mathrm{mbsf}$ (Table T2).

\section{Maximum past effective normal stress}

All of the $P^{\prime}{ }_{c}$ values for samples from Site C0011 are greater than the calculated values of in situ hydrostatic vertical effective stress at the equivalent sampling depths (Fig. F11); such OCR values are consistent with moderate levels of apparent overconsolidation. The individual values of $P^{\prime}{ }_{c}$ range from 0.76 to $11.37 \mathrm{MPa}$ (Casagrande method) and 0.72 to $11.08 \mathrm{MPa}$ (SED method). Differences between the values of $P^{\prime}{ }_{c}$ and $\sigma^{\prime}{ }_{v h}$ range from 0.43 to 6.01 MPa. We see no systematic changes in OCR with increasing depth and no obvious shifts in OCR across lithostratigraphic boundaries (Fig. F11).

Samples from Site C0012 yield $P^{\prime}{ }_{c}$ values that range from 0.50 to $7.33 \mathrm{MPa}$ (Casagrande method) and 0.47 to $8.25 \mathrm{MPa}$ (SED method). Differences between those values of $P_{c}^{\prime}$ and $\sigma_{\text {vh }}^{\prime}$ range from 0.26 to 4.75 $\mathrm{MPa}$, and the OCR ranges from 2.14 to 4.08. The magnitude of apparent overconsolidation at Site C0012 is consistently higher than for equivalent facies at Site C0011 (Fig. F11). On the other hand, changes in OCR are erratic with depth. We find unusually high OCR values within the hemipelagic/pyroclastic facies (Unit I), which has been affected by slumping within the upper $\sim 100 \mathrm{~m}$ (Expedition 333 Scientists, 2012b). Another excursion to higher OCR occurs near the top of the hemipelagic facies (Unit III); those strata were likewise affected by slumping and development of an unconformity (Expedition 322 Scientists, 2010b).

Results from Site C0018 are more straightforward. The values of $P_{c}^{\prime}$ range from 0.54 to $2.60 \mathrm{MPa}$ (Casagrande method) and 0.43 to $2.37 \mathrm{MPa}$ (SED method). Differences between the values of $P^{\prime}{ }_{c}$ and $\sigma_{v h}^{\prime}$ range from 0.11 to $0.70 \mathrm{MPa}$. OCR values vary from 0.76 (slightly underconsolidated) to 1.82 (modestly over- 
consolidated). OCR values show no obvious trend with depth, facies change, or depositional process (Fig. F11).

\section{Acknowledgments}

This research used samples provided by the Integrated Ocean Drilling Program (IODP). We thank Captains Minoura and Onda, as well as the drilling crew, laboratory technicians, and fellow scientists aboard the D/V Chikyu for their dedicated assistance during IODP Expeditions 322 and 333. Funding was granted by the Consortium for Ocean Leadership, US Science Support Program (grants T322A58 and T333B58) and the National Science Foundation (OCE-07518190). Burns and McDonnell contributed toward acquisition of the CRS system at the University of Missouri, and W. Likos provided technical advice. We thank A. Heupers for his review of the manuscript.

\section{References}

ASTM International, 2006. Standard test method for onedimensional consolidation properties of saturated cohesive soils using controlled-strain loading (Standard D4186-06). In Annual Book of ASTM Standards (Vol. 04.08): Soil and Rock (I): West Conshohocken, PA (Am. Soc. Testing Mater.) http://www.astm.org/DATABASE.CART/HISTORICAL/D4186-06.htm

Becker, D.E., Crooks, J.H.A., Been, K., and Jeffries, M.G., 1987. Work as a criterion for determining in situ and yield stresses in clays. Can. Geotech. J., 24(4):549-564. doi:10.1139/t87-070

Blum, P., 1997. Physical properties handbook: a guide to the shipboard measurement of physical properties of deep-sea cores. ODP Tech. Note, 26. doi:10.2973/ odp.tn.26.1997

Casagrande, A., 1936. The determination of pre-consolidation load and its practical significance. In Casagrande, A., Rutledge, P.C., and Watson, J.D. (Eds.), Proc. 1st Int. Conf. Soil Mech. Found. Eng. Am. Soc. Civ. Eng., 3:60-64.

Dugan, B., and Daigle, H., 2011. Data report: permeability, compressibility, stress state, and grain size of shallow sediments from Sites C0004, C0006, C0007, and C0008 of the Nankai accretionary complex. In Kinoshita, M., Tobin, H., Ashi, J., Kimura, G., Lallemant, S., Screaton, E.J., Curewitz, D., Masago, H., Moe, K.T., and the Expedition 314/315/316 Scientists, Proc. IODP, 314/315/316: Tokyo (Integrated Ocean Drilling Program Management International, Inc.). doi:10.2204/ iodp.proc.314315316.208.2011

Dugan, B., and Zhao, X., 2013. Data report: permeability of sediments from Sites C0011 and C0012, NanTroSEIZE Stage 2: subduction inputs. In Saito, S., Underwood, M.B., Kubo, Y., and the Expedition 322 Scientists, Proc. IODP, 322: Tokyo (Integrated Ocean Drilling Program
Management International, Inc.). doi:10.2204/ iodp.proc.322.208.2013

El-Dessouky, H.T., and Ettouney, H.M., 2002. Fundamentals of Salt Water Desalination: Amsterdam (Elsevier)

Expedition 316 Scientists, 2009. Expedition 316 methods. In Kinoshita, M., Tobin, H., Ashi, J., Kimura, G., Lallemant, S., Screaton, E.J., Curewitz, D., Masago, H., Moe, K.T., and the Expedition 314/315/316 Scientists, Proc. IODP, 314/315/316: Washington, DC (Integrated Ocean Drilling Program Management International, Inc.). doi:10.2204/iodp.proc.314315316.132.2009

Expedition 322 Scientists, 2010a. Site C0011. In Saito, S., Underwood, M.B., Kubo, Y., and the Expedition 322 Scientists, Proc. IODP, 322: Tokyo (Integrated Ocean Drilling Program Management International, Inc.). doi:10.2204/iodp.proc.322.103.2010

Expedition 322 Scientists, 2010b. Site C0012. In Saito, S., Underwood, M.B., Kubo, Y., and the Expedition 322 Scientists, Proc. IODP, 322: Tokyo (Integrated Ocean Drilling Program Management International, Inc.). doi:10.2204/iodp.proc.322.104.2010

Expedition 333 Scientists, 2012a. Site C0011. In Henry, P., Kanamatsu, T., Moe, K., and the Expedition 333 Scientists, Proc. IODP, 333: Tokyo (Integrated Ocean Drilling Program Management International, Inc.). doi:10.2204/iodp.proc.333.104.2012

Expedition 333 Scientists, 2012b. Site C0012. In Henry, P., Kanamatsu, T., Moe, K., and the Expedition 333 Scientists, Proc. IODP, 333: Tokyo (Integrated Ocean Drilling Program Management International, Inc.). doi:10.2204/iodp.proc.333.105.2012

Expedition 333 Scientists, 2012c. Site C0018. In Henry, P., Kanamatsu, T., Moe, K., and the Expedition 333 Scientists, Proc. IODP, 333: Tokyo (Integrated Ocean Drilling Program Management International, Inc.). doi:10.2204/iodp.proc.333.103.2012

Fofonoff, N.P., 1985. Physical properties of seawater: a new salinity scale and equation of state for seawater. J. Geophys. Res.: Oceans, 90(C2):3332-3342. doi:10.1029/ JC090iC02p03332

Guo, J., Likos, W.J., Underwood, M.B., Skarbek, R.M., Adamson, N., and Saffer, D., 2011. Data report: consolidation characteristics of sediments from Sites C0002, C0006, and C0007, IODP Expeditions 315 and 316, NanTroSEIZE Stage 1. In Kinoshita, M., Tobin, H., Ashi, J., Kimura, G., Lallemant, S., Screaton, E.J., Curewitz, D., Masago, H., Moe, K.T., and the Expedition 314/315/316 Scientists, Proc. IODP, 314/315/316: Washington, DC (Integrated Ocean Drilling Program Management International, Inc.). doi:10.2204/ iodp.proc.314315316.213.2011

Holtz, R.D., and Kovacs, W.D., 1981. An Introduction to Geotechnical Engineering: Englewood Cliffs, NJ (PrenticeHall).

Long, H., Flemings, P.B., Germaine, J.T., Saffer, D.M., and Dugan, B., 2008. Data report: consolidation characteristics of sediments from IODP Expedition 308, Ursa Basin, Gulf of Mexico. In Flemings, P.B., Behrmann, J.H., John, C.M., and the Expedition 308 Scientists, Proc. IODP, 308: College Station, TX (Integrated Ocean Drilling Pro- 
gram Management International, Inc.). doi:10.2204/ iodp.proc.308.204.2008

Lunne, T., Berre, T., and Strandvik, S., 1997. Sample disturbance effects in soft low plastic Norwegian clay. Publ.Nor. Geotek. Inst., 204:81-102.

Neuzil, C.E., 1994. How permeable are clays and shales? Water Resour. Res., 30(2):145-150. doi:10.1029/ 93WR02930

Saffer, D., Guo, J., Underwood, M.B., Likos, W., Skarbek, R.M., Song, I., and Gildow, M., 2011. Data report: consolidation, permeability, and fabric of sediments from the Nankai continental slope, IODP Sites C0001, C0008, and C0004. In Kinoshita, M., Tobin, H., Ashi, J., Kimura, G., Lallemant, S., Screaton, E.J., Curewitz, D., Masago, H., Moe, K.T., and the Expedition 314/315/316 Scientists, Proc. IODP, 314/315/316: Washington, DC (Integrated Ocean Drilling Program Management International, Inc.). doi:10.2204/ iodp.proc.314315316.218.2011

Screaton, E., Rowe, K., Sutton, J., and Atalan, G., 2013. Data report: permeabilities of Expedition 322 and 333 sediments from offshore the Kii Peninsula, Japan. In Saito, S., Underwood, M.B., Kubo, Y., and the Expedition 322 Scientists, Proc. IODP, 322: Tokyo (Integrated Ocean Drilling Program Management International, Inc.). doi:10.2204/iodp.proc.322.210.2013

Song, C., Ekinci, M.K., and Underwood, M.B., in press. Data report: permeability and microfabric of mud(stone) samples from IODP Sites C0011 and C0012, NanTroSEIZE subduction inputs. In Saito, S., Underwood, M.B., Kubo, Y., and the Expedition 322 Scientists, Proc. IODP, 322: Tokyo (Integrated Ocean Drilling Program Management International, Inc.). doi:10.2204/ iodp/proc.322.211.2014

Tobin, H.J., and Kinoshita, M., 2006. NanTroSEIZE: the IODP Nankai Trough Seismogenic Zone Experiment. Sci. Drill., 2:23-27. doi:10.2204/iodp.sd.2.06.2006

Initial receipt: 20 August 2012

Acceptance: 10 October 2013

Publication: 1 October 2014

MS 322-209 
Figure F1. Map showing location of sites drilled during NanTroSEIZE Expeditions 322 and 333 (from Expedition 333 Scientists, 2012a). Inset shows location of Nankai Trough.

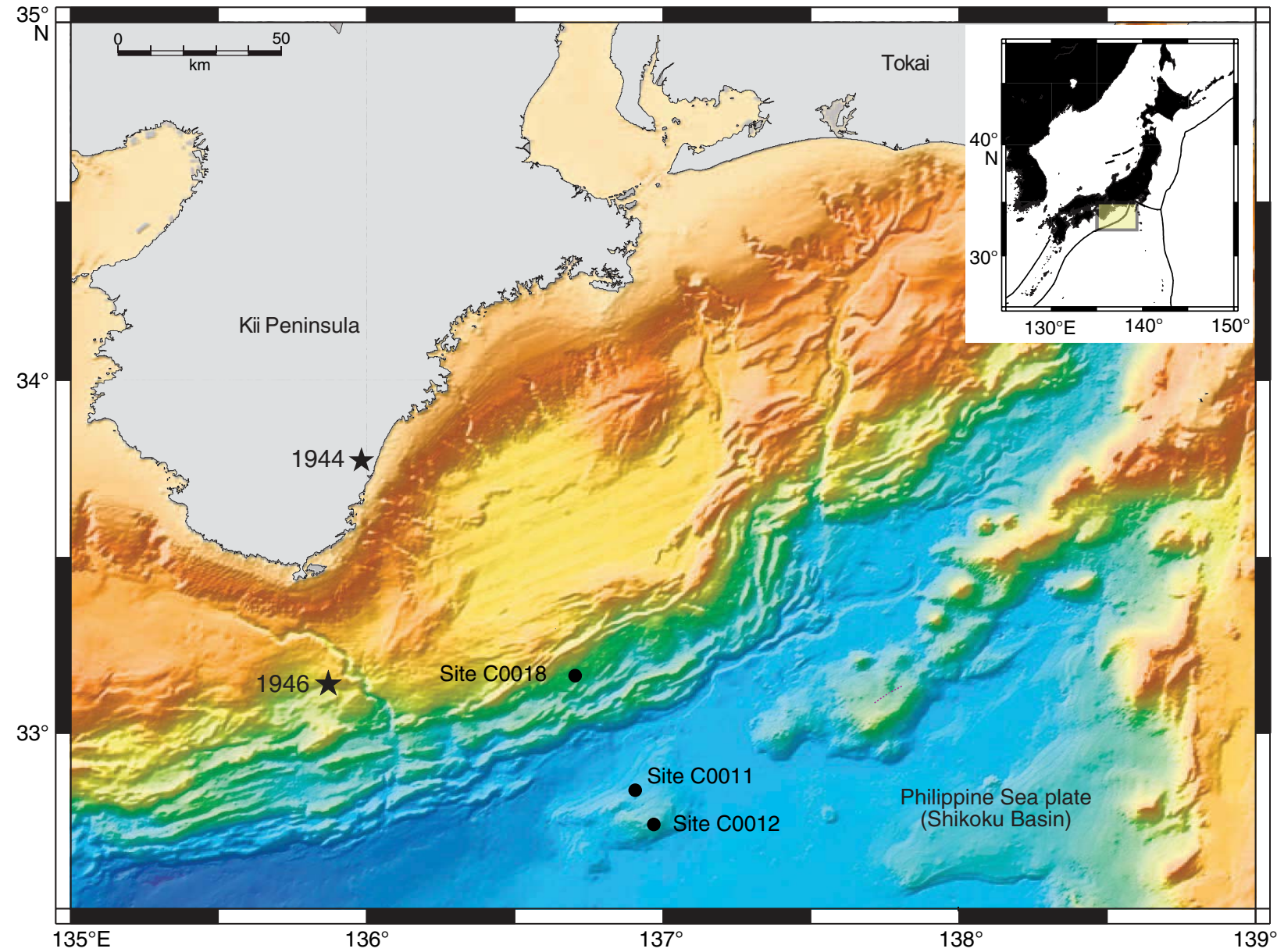


Figure F2. Simplified lithostratigraphic columns for Sites C0011, C0012, and C0018 with bedding dips at the locations of samples used for CRSC tests (red dots). Modified from Expedition 322 Scientists (2010a, 2010b) and Expedition 333 Scientists (2012a, 2012b, 2012c).

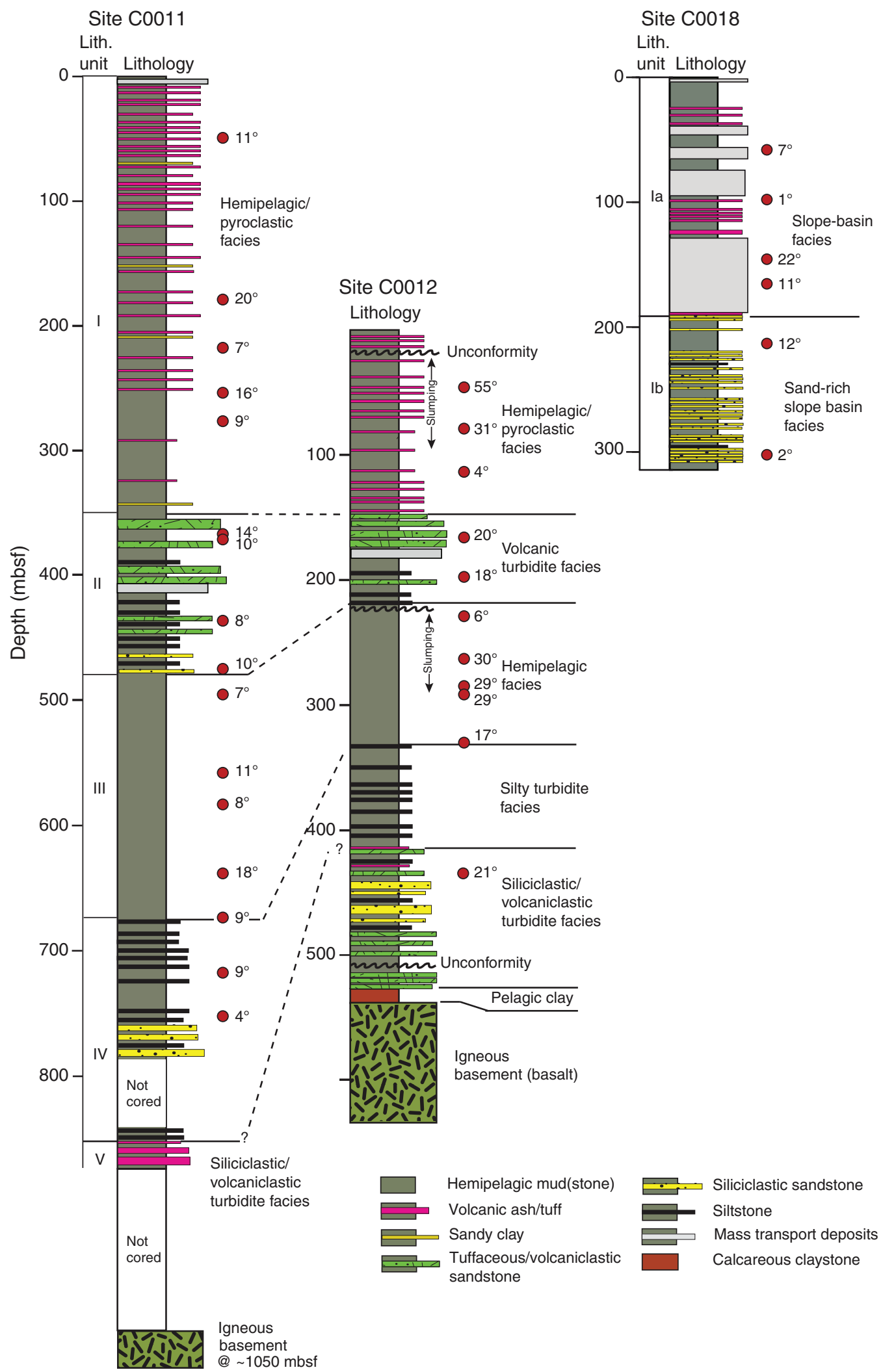


Figure F3. Plot of void ratio versus vertical effective stress to illustrate determination of $P^{\prime}{ }_{c}$ following Casagrande (1936). Plot of strain energy density versus vertical effective stress to illustrate the SED method of Becker et al. (1987), where $P^{\prime}{ }_{c}$ is defined by the intersection of line segments fit to the initial slope of the reloading curve and to the virgin compression curve.
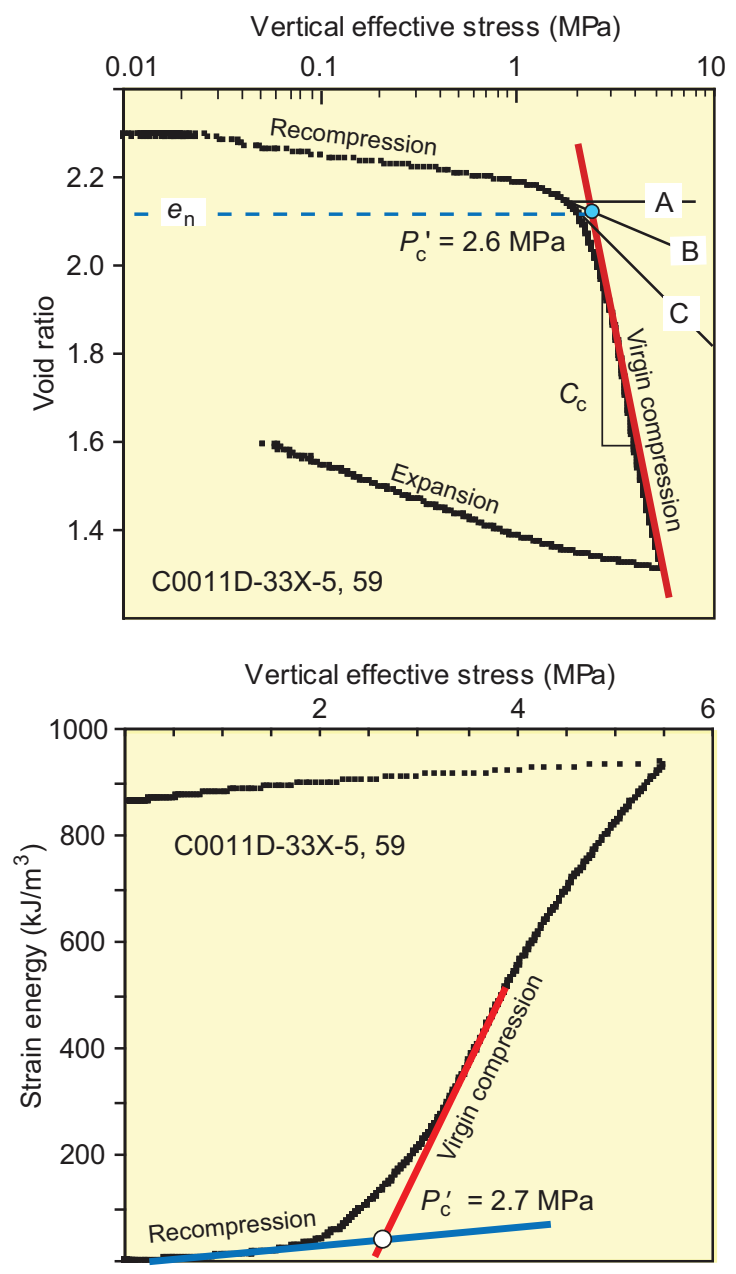
Figure F4. Virgin curves from consolidation tests of samples from Site C0011, segregated by lithostratigraphic unit.

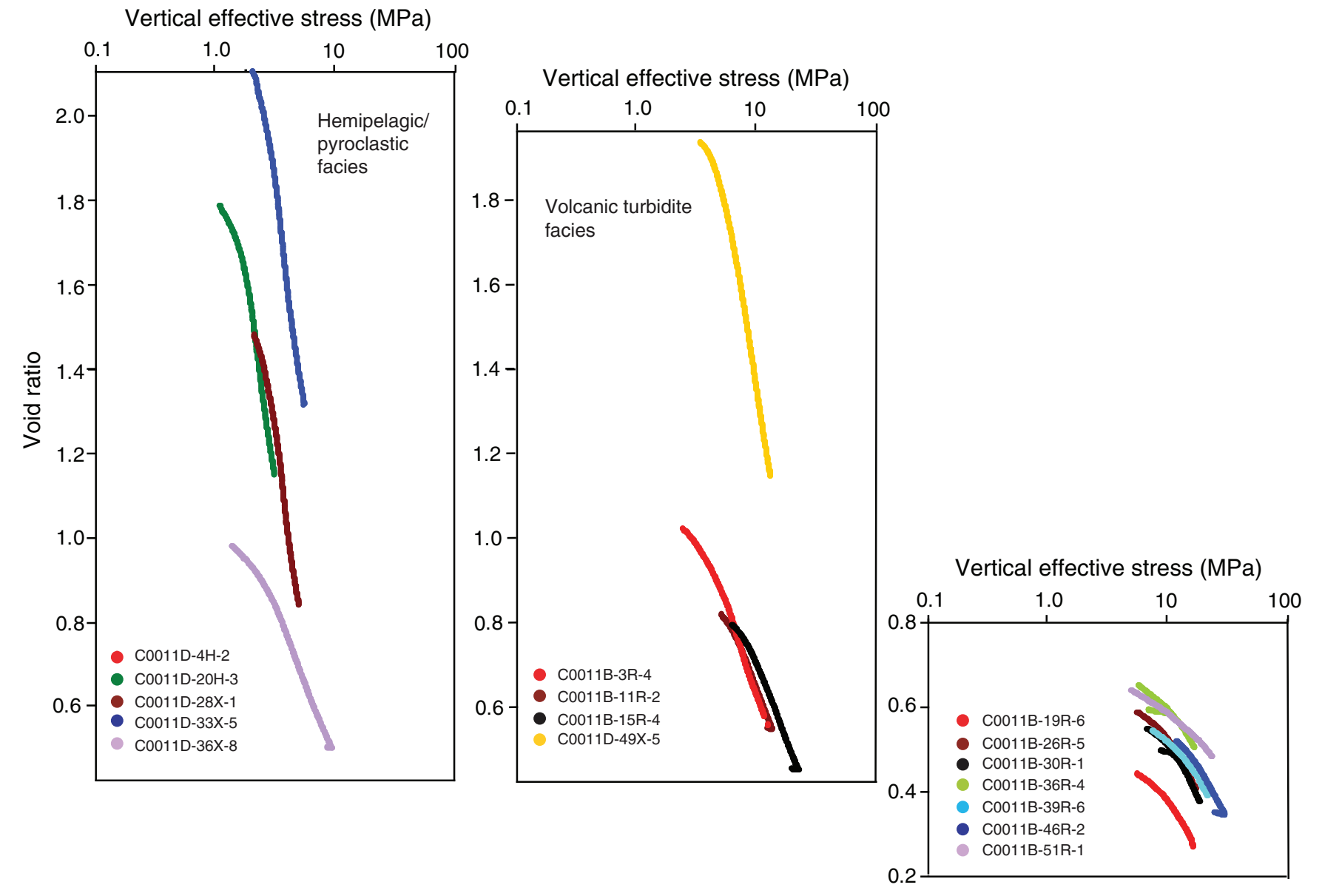


Figure F5. Virgin curves from consolidation tests of samples from Site C0012, segregated by lithostratigraphic unit.

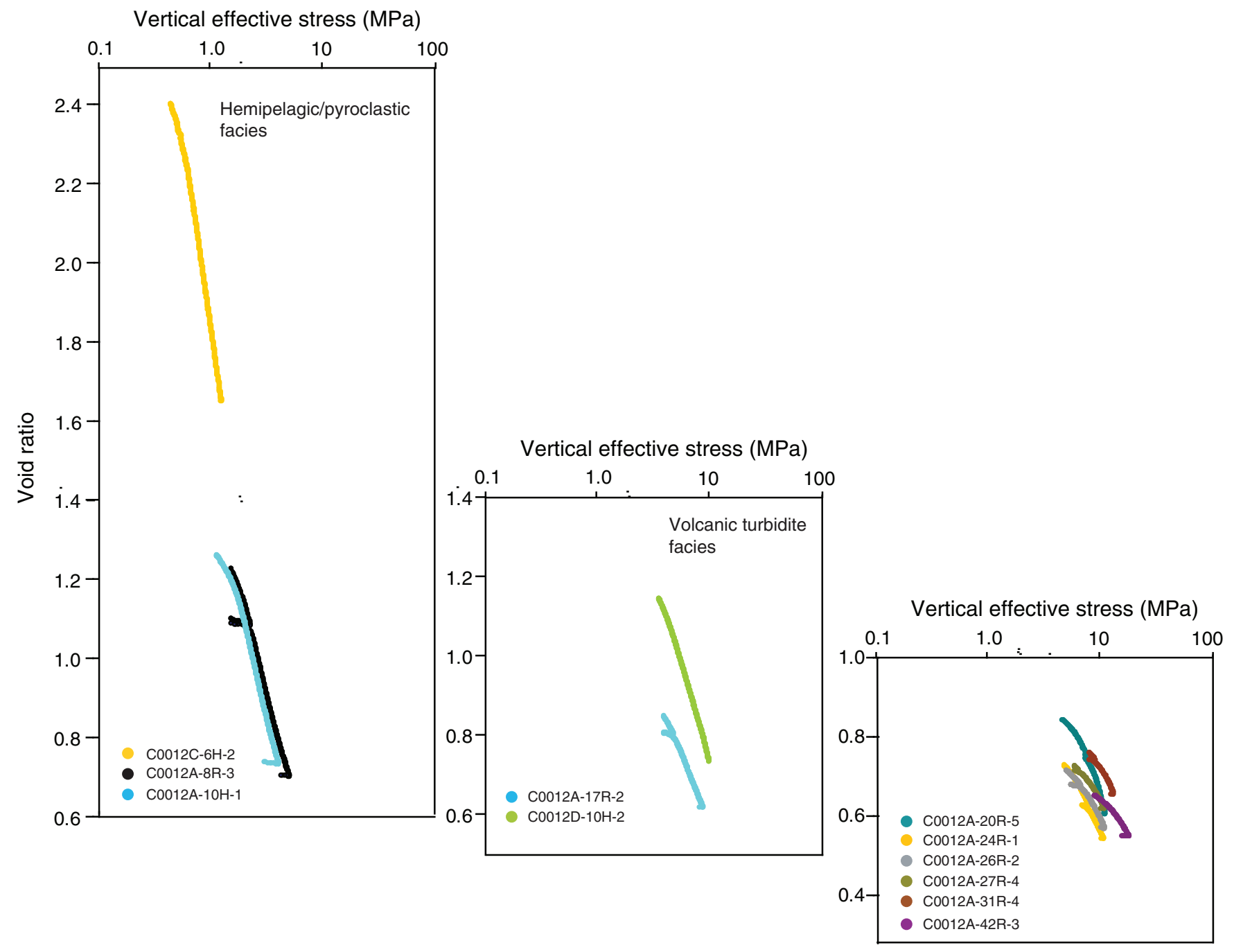


Figure F6. Virgin curves from consolidation tests of samples from Site C0018.

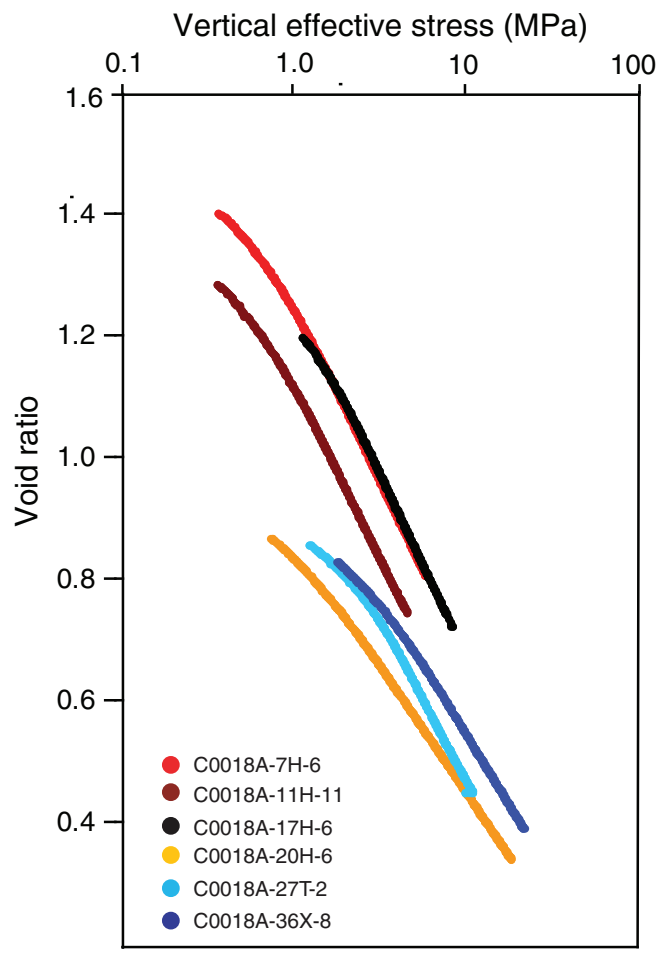


Figure F7. Values of compression index plotted as a function of depth, Sites C0011, C0012, and C0018.

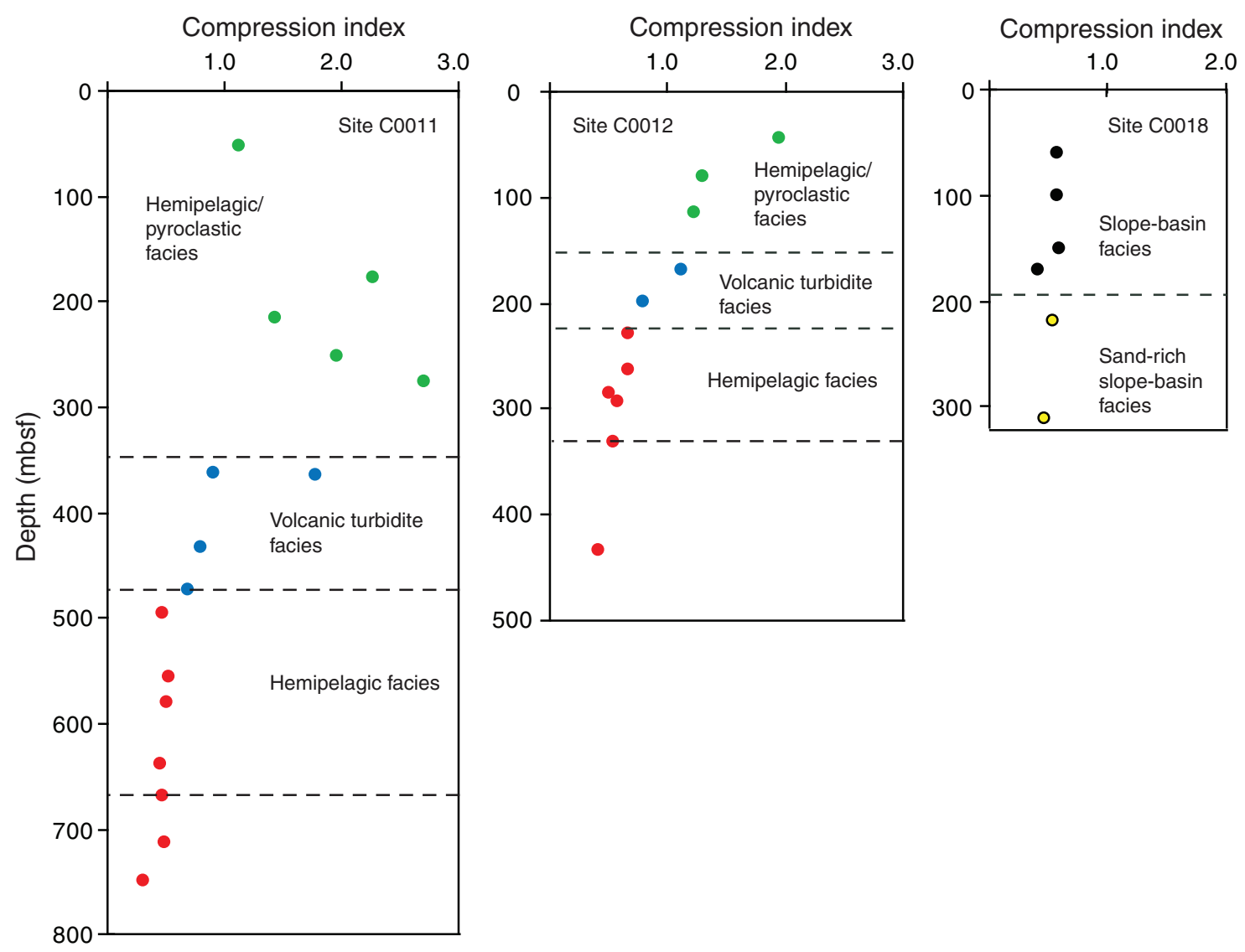


Figure F8. Intrinsic permeability under laboratory testing conditions plotted as a function of vertical effective stress and porosity, Sites C0011 and C0012. Results are merged according to lithostratigraphic unit. Data from the transient phases of the tests were not used.

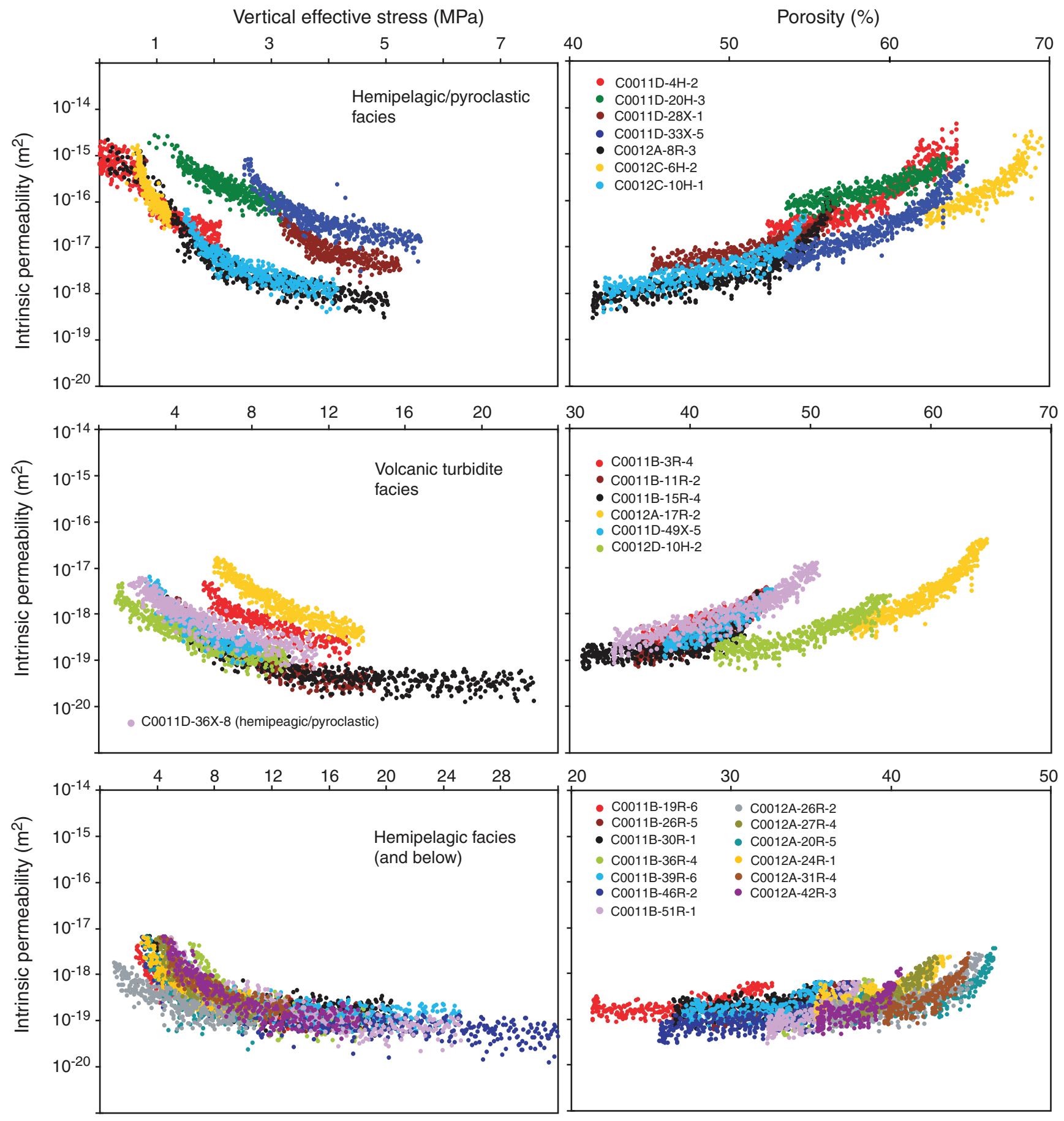


Figure F9. In situ intrinsic permeability plotted as a function of depth at Sites C0011, C0012, and C0018. Values were determined by projecting the permeability-porosity trend for each mudstone sample to the value of in situ void ratio at the intersection point of $P^{\prime}{ }$. Complementary data from CRSC tests and flow-through tests (at lower confining pressures) are shown for comparison (Screaton et al., 2013; Dugan and Zhao, 2013; Song et al., in press).

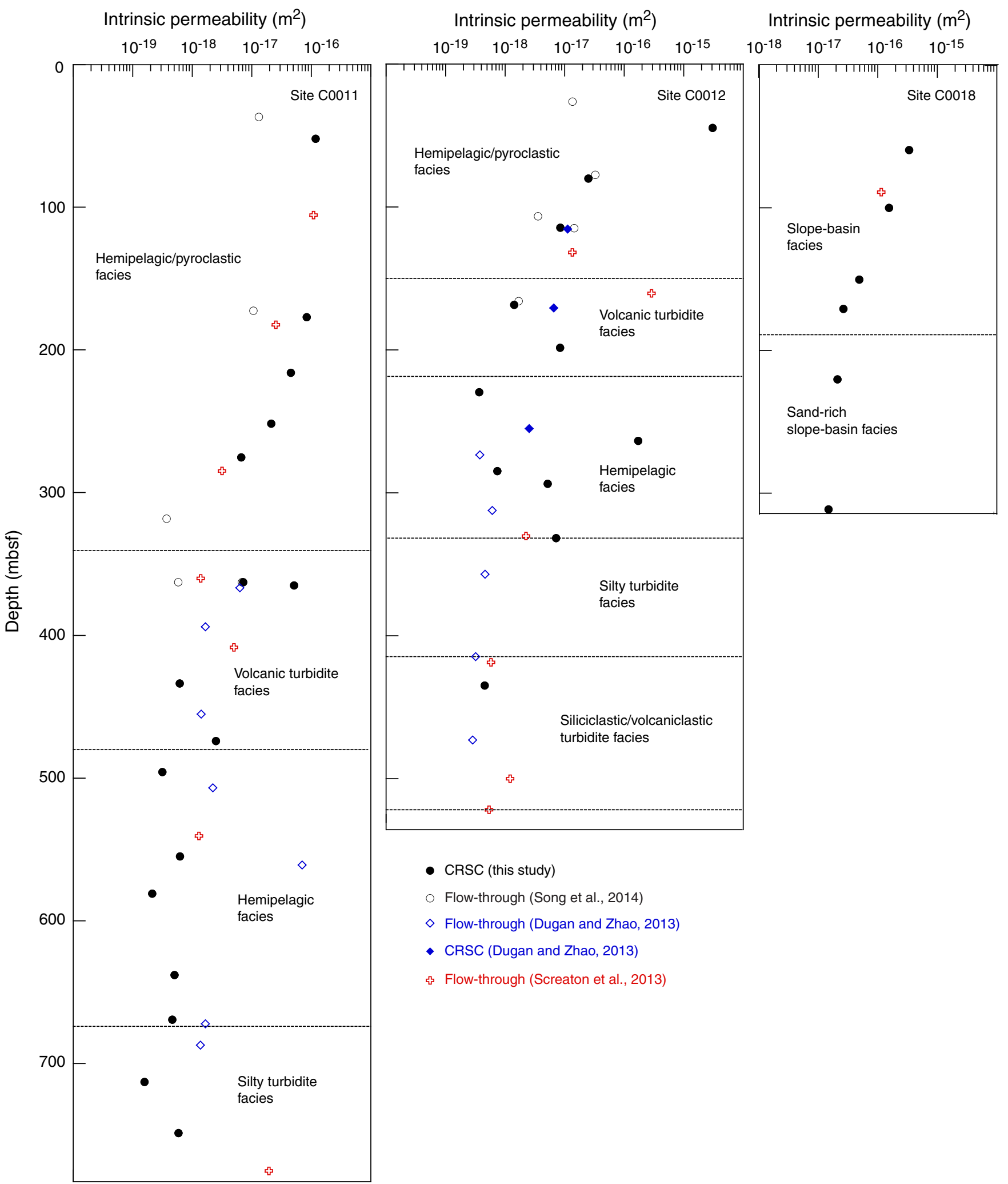


Figure F10. Intrinsic permeability under laboratory testing conditions plotted as a function of vertical effective stress and porosity, Site C0018. Data from the transient phases of the tests were not used.

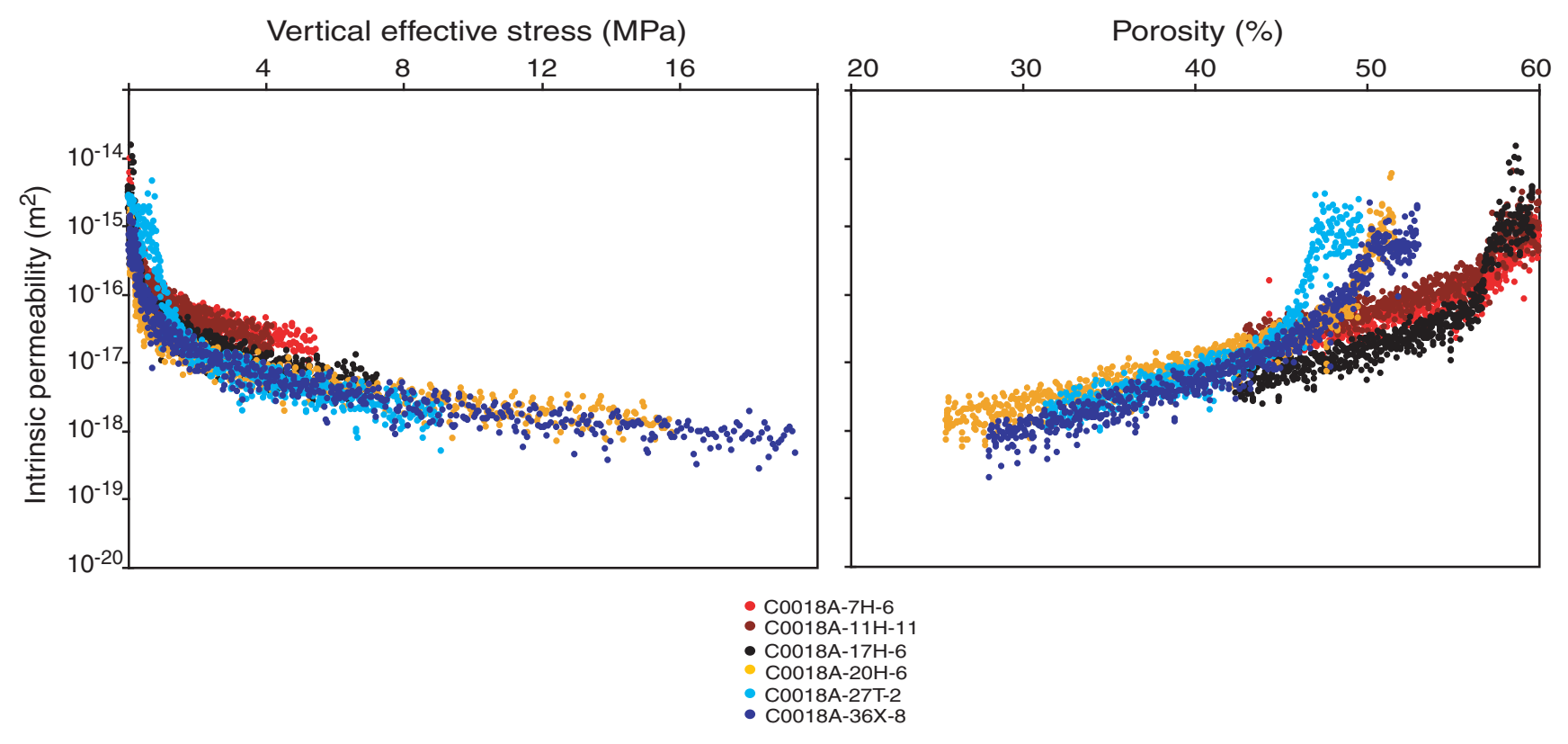


Figure F11. Values of overconsolidation ratio plotted as a function of depth, Sites C0011, C0012, and C0018.

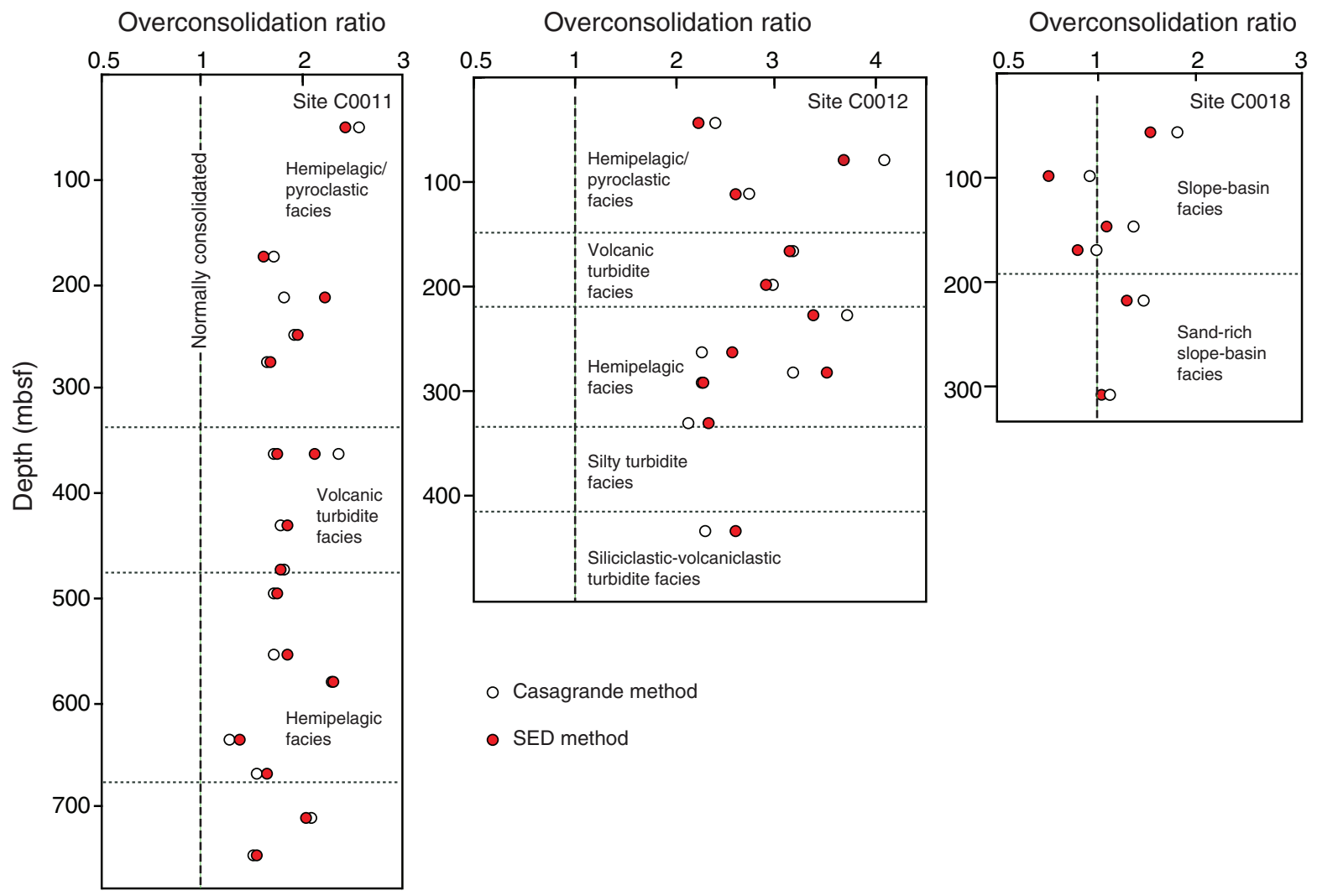


Table T1. Rating of sample disturbance for test specimens from Sites C0011, C0012, and C0018.

\begin{tabular}{|c|c|c|c|c|c|c|c|}
\hline \multirow{2}{*}{$\begin{array}{l}\text { Site, hole, core, section, } \\
\text { interval }(\mathrm{cm})\end{array}$} & \multirow{2}{*}{$\begin{array}{l}\text { Top WR depth } \\
\text { (mbsf) }\end{array}$} & \multirow{2}{*}{$\begin{array}{l}\text { Bedding dip } \\
\left({ }^{\circ}\right)\end{array}$} & \multirow[b]{2}{*}{ Lith. unit } & \multicolumn{2}{|c|}{ Void ratio } & \multirow[b]{2}{*}{$\Delta e / e_{\mathrm{i}}$} & \multirow[b]{2}{*}{ Rating } \\
\hline & & & & Initial & In situ & & \\
\hline 333-C0011D-4H-2, 122 & 51.64 & 11 & 1 & 1.80 & 1.59 & 0.12 & Very poor \\
\hline 333-C0011D-20H-3, 0 & 176.83 & 20 & 1 & 2.05 & 1.77 & 0.14 & Poor \\
\hline 333-C0011D-28X-1, 73 & 215.73 & 7 & I & 1.61 & 1.48 & 0.08 & Poor \\
\hline 333-C0011D-33X-5, 59 & 251.37 & 16 & I & 2.30 & 2.00 & 0.13 & Poor \\
\hline 333-C0011D-36X-8, 56 & 275.02 & 9 & 1 & 1.15 & 0.95 & 0.17 & Very poor \\
\hline 322-C0011B-3R-4, 120 & 362.59 & 14 & II & 1.15 & 1.00 & 0.13 & Poor \\
\hline 333-C0011D-49X-5, 60 & 364.80 & 10 & II & 2.07 & 1.97 & 0.05 & Good to fair \\
\hline 322-C0011B-11R-2, 70 & 433.60 & 8 & II & 1.00 & 0.88 & 0.13 & Poor \\
\hline 322-C0011B-15R-4, 104 & 473.75 & 10 & II & 1.02 & 0.88 & 0.13 & Poor \\
\hline 322-C0011B-19R-6, 0 & 495.61 & 7 & III & 0.63 & 0.47 & 0.25 & Very poor \\
\hline 322-C0011B-26R-5, 106 & 554.74 & 11 & III & 0.77 & 0.61 & 0.21 & Very poor \\
\hline 322-C0011B-30R-1, 32 & 580.72 & 8 & III & 0.66 & 0.52 & 0.21 & Very poor \\
\hline 322-C0011B-36R-4, 115 & 637.77 & 18 & III & 0.83 & 0.70 & 0.16 & Very poor \\
\hline 322-C0011B-39R-6, 45 & 669.20 & 9 & III & 0.73 & 0.58 & 0.21 & Very poor \\
\hline 322-C0011B-46R-2, 10 & 712.71 & 9 & IV & 0.74 & 0.56 & 0.25 & Very poor \\
\hline 322-C0011B-51R-1, 122 & 748.62 & 4 & IV & 0.78 & 0.59 & 0.24 & Very poor \\
\hline $333-\mathrm{C} 0012 \mathrm{C}-6 \mathrm{H}-2,60$ & 44.52 & 55 & 1 & 2.79 & 2.47 & 0.12 & Very poor \\
\hline 333-C0012C-10H-1, 105 & 80.05 & 31 & 1 & 1.47 & 1.28 & 0.13 & Very poor \\
\hline $322-C 0012 A-8 R-3,3$ & 114.35 & 4 & 1 & 1.47 & 1.24 & 0.15 & Very poor \\
\hline 333-C0012D-10H-2, 89 & 168.23 & 20 & II & 1.38 & 1.17 & 0.15 & Very poor \\
\hline 322-C0012A-17R-2, 19 & 198.39 & 18 & II & 1.04 & 0.90 & 0.14 & Very poor \\
\hline 322-C0012A-20R-5, 20 & 229.44 & 6 & III & 1.07 & 0.90 & 0.16 & Very poor \\
\hline 322-C0012A-24R-1, 30 & 263.50 & 30 & III & 0.90 & 0.74 & 0.18 & Very poor \\
\hline 322-C0012A-26R-2, 100 & 284.61 & 29 & III & 0.92 & 0.65 & 0.29 & Very poor \\
\hline $322-C 0012 A-27 R-4,0$ & 293.46 & 29 & III & 0.93 & 0.81 & 0.13 & Very poor \\
\hline $322-C 0012 A-31 R-4,46$ & 331.53 & 17 & III & 0.96 & 0.81 & 0.16 & Very poor \\
\hline $322-C 0012 A-42 R-3,20$ & 434.66 & 21 & V & 0.86 & 0.66 & 0.23 & Very poor \\
\hline 333-C0018A-7H-6, 0 & 59.27 & 7 & la/MTD & 1.56 & 1.38 & 0.12 & Poor \\
\hline 333-C0018A-11H-11, 0 & 99.73 & 1 & la & 1.50 & 1.30 & 0.14 & Very poor \\
\hline 333-C0018A-17H-6, 20 & 150.01 & 22 & la/MTD & 1.48 & 1.24 & 0.16 & Very poor \\
\hline 333-C0018A-20H-6, 126 & 170.36 & 11 & la/MTD & 1.07 & 0.85 & 0.20 & Very poor \\
\hline 333-C0018A-27T-2, 38 & 219.84 & 12 & $\mathrm{lb}$ & 1.09 & 0.80 & 0.27 & Very poor \\
\hline 333-C0018A-36X-8, 35 & 311.12 & 2 & $\mathrm{lb}$ & 1.13 & 0.80 & 0.29 & Very poor \\
\hline
\end{tabular}

WR $=$ whole round. Void ratios are from intersection point of $P_{c}^{\prime}$ using SED method. Ratings follow criteria of Lunne et al. (1997). MTD = mass transport deposit. 
Table T2. CRSC test conditions, specimen properties, and test results for samples from Sites C0011, C0012, and C0018.

\begin{tabular}{|c|c|c|c|c|c|c|c|c|c|c|c|c|c|}
\hline \multirow[b]{2}{*}{$\begin{array}{l}\text { Site, hole, core, section, } \\
\text { interval }(\mathrm{cm})\end{array}$} & \multirow[b]{2}{*}{$\begin{array}{l}\text { Top WR depth } \\
\text { (mbsf) }\end{array}$} & \multirow[b]{2}{*}{$\begin{array}{l}\text { Strain rate } \\
(\% / h)\end{array}$} & \multirow[b]{2}{*}{$\begin{array}{c}U_{\mathrm{b}} \\
(\mathrm{kPa})\end{array}$} & \multirow[b]{2}{*}{$\begin{array}{c}H_{\circ} \\
(\mathrm{mm})\end{array}$} & \multirow[b]{2}{*}{$C_{c}$} & \multirow[b]{2}{*}{$\begin{array}{c}c_{v} \\
\left(\mathrm{~m}^{2} / \mathrm{s}\right)\end{array}$} & \multicolumn{2}{|c|}{$P_{c}^{\prime}(\mathrm{MPa})$} & \multirow[b]{2}{*}{$\begin{array}{l}\sigma_{\mathrm{vh}}^{\prime} \\
(\mathrm{MPa})\end{array}$} & \multicolumn{2}{|c|}{ OCR } & \multicolumn{2}{|c|}{ In situ condition } \\
\hline & & & & & & & $\begin{array}{l}\text { Casa- } \\
\text { grande }\end{array}$ & SED & & $\begin{array}{l}\text { Casa- } \\
\text { grande }\end{array}$ & SED & $K(\mathrm{~m} / \mathrm{s})$ & $k\left(m^{2}\right)$ \\
\hline 333-C0011D-4H-2, 122 & 51.64 & 0.50 & 204 & 25.40 & 1.12 & $3.27 \mathrm{E}-07$ & 0.76 & 0.72 & 0.29 & 2.59 & 2.46 & $6.70 \mathrm{E}-10$ & 1.17E-16 \\
\hline 333-C0011D-20H-3, 0 & 176.83 & 0.50 & 204 & 23.06 & 2.27 & $9.60 \mathrm{E}-08$ & 1.66 & 1.55 & 0.96 & 1.74 & 1.63 & $6.62 \mathrm{E}-10$ & 8.35E-17 \\
\hline 333-C0011D-28X-1, 73 & 215.73 & 0.60 & 200 & 23.52 & 1.45 & $1.09 \mathrm{E}-07$ & 2.12 & 2.60 & 1.16 & 1.82 & 2.24 & $4.58 \mathrm{E}-10$ & $4.48 \mathrm{E}-17$ \\
\hline 333-C0011D-33X-5, 59 & 251.37 & 0.60 & 200 & 23.98 & 1.96 & $3.31 \mathrm{E}-08$ & 2.64 & 2.70 & 1.36 & 1.94 & 1.98 & $1.34 \mathrm{E}-10$ & $2.11 \mathrm{E}-17$ \\
\hline 333-C0011D-36X-8, 56 & 275.02 & 0.60 & 200 & 19.68 & 2.70 & 2.00E-08 & 2.57 & 2.60 & 1.54 & 1.67 & 1.70 & 5.69E-11 & $6.53 \mathrm{E}-18$ \\
\hline 322-C0011B-3R-4, 120 & 362.59 & 0.50 & 204 & 24.40 & 0.92 & $2.38 \mathrm{E}-08$ & 3.85 & 3.94 & 2.21 & 1.74 & 1.78 & $6.97 \mathrm{E}-11$ & 7.15E-18 \\
\hline 333-C0011D-49X-5, 60 & 364.80 & 0.60 & 200 & 24.74 & 1.78 & $2.65 \mathrm{E}-08$ & 5.29 & 4.79 & 2.23 & 2.37 & 2.15 & 8.33E-10 & $5.08 \mathrm{E}-17$ \\
\hline 322-C0011B-11R-2, 70 & 433.60 & 0.50 & 204 & 24.40 & 0.80 & $1.60 \mathrm{E}-08$ & 5.05 & 5.24 & 2.82 & 1.79 & 1.86 & $8.90 \mathrm{E}-12$ & $6.08 \mathrm{E}-19$ \\
\hline 322-C0011B-15R-4, 104 & 473.75 & 0.50 & 204 & 24.40 & 0.69 & $2.33 \mathrm{E}-08$ & 5.75 & 5.71 & 3.14 & 1.83 & 1.82 & $4.51 \mathrm{E}-11$ & 2.47E-18 \\
\hline 322-C0011B-19R-6, 0 & 495.61 & 0.50 & 204 & 23.40 & 0.46 & $1.46 \mathrm{E}-08$ & 5.75 & 5.88 & 3.35 & 1.72 & 1.76 & $4.93 \mathrm{E}-12$ & $3.13 \mathrm{E}-19$ \\
\hline 322-C0011B-26R-5, 106 & 554.74 & 0.50 & 204 & 22.35 & 0.52 & $1.49 \mathrm{E}-08$ & 6.73 & 7.27 & 3.89 & 1.73 & 1.87 & $8.73 \mathrm{E}-12$ & $6.16 \mathrm{E}-19$ \\
\hline 322-C0011B-30R-1, 32 & 580.72 & 0.3 & 204 & 25.40 & 0.52 & $2.03 \mathrm{E}-08$ & 9.52 & 9.52 & 4.12 & 2.31 & 2.31 & $3.69 \mathrm{E}-12$ & $1 \mathrm{E}-19$ \\
\hline 322-C0011B-36R-4, 115 & 637.77 & 0.30 & 200 & 25.40 & 0.46 & $1.29 \mathrm{E}-08$ & 6.08 & 6.51 & 4.66 & 1.30 & 1.40 & -11 & $5.01 \mathrm{E}-19$ \\
\hline 322-C0011B-39R-6, 45 & 669.20 & 0.30 & 200 & 24.53 & 0.46 & $2.94 \mathrm{E}-08$ & 7.76 & 8.33 & 4.95 & 1.57 & 1.68 & $9.30 \mathrm{E}-12$ & 4.59E-19 \\
\hline 322-C0011B-46R-2, 10 & 712.71 & 0.30 & 201 & 23.42 & 0.50 & $1.54 \mathrm{E}-08$ & 11.37 & 11.08 & 5.36 & 2.12 & 2.07 & $2.99 \mathrm{E}-12$ & $1.57 \mathrm{E}-19$ \\
\hline 322-C0011B-51R-1, 122 & 748.62 & 0.30 & 201 & 25.27 & 0.31 & $2.00 \mathrm{E}-08$ & 8.72 & 8.99 & 5.73 & 1.52 & 1.57 & $7.66 \mathrm{E}-12$ & $5.84 \mathrm{E}-19$ \\
\hline 333-C0012C-6H-2, 60 & 44.52 & 0.80 & 200 & 25.40 & 1.94 & $2.54 \mathrm{E}-07$ & 0.50 & 0.47 & 0.21 & 2.41 & 2.26 & $1.38 \mathrm{E}-08$ & 3.03E-15 \\
\hline 333-C0012C-10H-1, 105 & 80.05 & 0.70 & 200 & 23.59 & 1.30 & $2.69 \mathrm{E}-08$ & 1.61 & 1.45 & 0.39 & 4.08 & 3.68 & $1.24 \mathrm{E}-10$ & $2.49 \mathrm{E}-17$ \\
\hline 322-C0012A-8R-3, 3 & 114.35 & 0.50 & 204 & 23.75 & 1.23 & $2.13 \mathrm{E}-08$ & 1.66 & 1.57 & 0.60 & 2.74 & 2.61 & $5.01 \mathrm{E}-11$ & 8.39E-18 \\
\hline 333-C0012D-10H-2, 89 & 168.23 & 0.60 & 200 & 23.84 & 1.12 & $9.38 \mathrm{E}-09$ & 3.07 & 3.06 & 0.97 & 3.18 & 3.16 & $8.65 \mathrm{E}-12$ & $1.40 \mathrm{E}-18$ \\
\hline 322-C0012A-17R-2, 19 & 198.39 & 0.50 & 200 & 24.13 & 0.80 & $1.22 \mathrm{E}-08$ & 3.50 & 3.43 & 1.18 & 2.98 & 2.91 & $\mathrm{E}-11$ & $8.29 \mathrm{E}-18$ \\
\hline 322-C0012A-20R-5, 20 & 229.44 & 0.50 & 200 & 24.08 & 0.66 & $1.14 \mathrm{E}-08$ & 5.29 & 4.82 & 1.42 & 3.72 & 3.39 & 3.84E-12 & 3.65E-19 \\
\hline 322-C0012A-24R-1, 30 & 263.50 & 0.50 & 204 & 25.40 & 0.66 & $1.12 \mathrm{E}-08$ & 3.87 & 4.39 & 1.71 & 2.27 & 2.57 & $2.00 \mathrm{E}-10$ & $1.70 \mathrm{E}-16$ \\
\hline 322-C0012A-26R-2, 100 & 284.61 & 0.50 & 200 & 21.94 & 0.51 & $9.52 \mathrm{E}-09$ & 6.06 & 6.65 & 1.89 & 3.20 & 3.51 & $1.88 \mathrm{E}-12$ & 7.35E-19 \\
\hline 322-C0012A-27R-4, 0 & 293.46 & 0.50 & 201 & 25.40 & 0.57 & $1.18 \mathrm{E}-08$ & 4.45 & 4.51 & 1.96 & 2.27 & 2.30 & 5.57E-11 & 5.10E-18 \\
\hline 322-C0012A-31R-4, 46 & 331.53 & 0.50 & 204 & 25.40 & 0.54 & $1.38 \mathrm{E}-08$ & 4.84 & 5.31 & 2.26 & 2.14 & 2.35 & $2.81 \mathrm{E}-11$ & $7.14 \mathrm{E}-18$ \\
\hline 322-C0012A-42R-3, 20 & 434.66 & 0.50 & 205 & 22.78 & 0.42 & $1.95 \mathrm{E}-08$ & 7.33 & 8.25 & 3.17 & 2.31 & 2.60 & $4.16 \mathrm{E}-12$ & $4.45 \mathrm{E}-19$ \\
\hline 333-C0018A-7H-6, 0 & 59.27 & 0.55 & 200 & 25.40 & 0.59 & 1.27E-06 & 0.59 & 0.51 & 0.33 & 1.82 & 1.57 & $1.41 \mathrm{E}-09$ & $3.33 \mathrm{E}-16$ \\
\hline $333-\mathrm{C} 0018 \mathrm{~A}-11 \mathrm{H}-11,0$ & 99.73 & 0.60 & 200 & 25.40 & 0.58 & $7.80 \mathrm{E}-07$ & 0.54 & 0.44 & 0.57 & 0.95 & 0.76 & $1.51 \mathrm{E}-09$ & $1.52 \mathrm{E}-16$ \\
\hline 333-C0018A-17H-6, 20 & 150.01 & 0.65 & 200 & 24.16 & 0.60 & $3.78 \mathrm{E}-07$ & 1.28 & 1.03 & 0.92 & 1.39 & 1.12 & 3.47E-10 & $4.85 \mathrm{E}-17$ \\
\hline 333-C0018A-2OH-6, 126 & 170.36 & 0.65 & 200 & 23.85 & 0.42 & $2.48 \mathrm{E}-07$ & 1.08 & 0.93 & 1.08 & 1.01 & 0.86 & $2.55 \mathrm{E}-10$ & $2.61 \mathrm{E}-17$ \\
\hline 333-C0018A-27T-2, 38 & 219.84 & 0.65 & 204 & 24.10 & 0.54 & $1.60 \mathrm{E}-07$ & 2.19 & 1.94 & 1.48 & 1.48 & 1.31 & $1.23 \mathrm{E}-10$ & 2.07E-17 \\
\hline 333-C0018A-36X-8, 35 & 311.12 & 0.65 & 200 & 24.38 & 0.47 & $1.64 \mathrm{E}-07$ & 2.61 & 2.38 & 2.26 & 1.16 & 1.05 & 1.37E-10 & 1.47E-17 \\
\hline
\end{tabular}

$\mathrm{WR}=$ whole round. $C_{\mathrm{c}}$ and $c_{\mathrm{v}}$ are based on uniaxial stress path, which may differ from actual loading path. Hydraulic conductivity $(K)$ computed from values of intrinsic permeability plus in situ fluid density and viscosity at temperature of burial depth. $k$ from intersection point of $P_{c}^{\prime}$ using SED method, under uniaxial loading path. 
Table T3. Nomenclature and symbols for variables.

\begin{tabular}{|c|c|c|c|}
\hline Symbol & Definition & Dimensions & SI units \\
\hline$C_{c}$ & Compression index & Dimensionless & \\
\hline$c_{\mathrm{v}}$ & Coefficient of consolidation & $\mathrm{L}^{2} / \mathrm{T}$ & $\mathrm{m}^{2} / \mathrm{s}$ \\
\hline$e$ & Void ratio & Dimensionless & \\
\hline$e_{\mathrm{i}}$ & Initial void ratio measured on specimen & Dimensionless & \\
\hline$e_{\mathrm{n}}$ & In situ void ratio & Dimensionless & \\
\hline $\mathrm{g}$ & Gravitational acceleration & $\mathrm{M} / \mathrm{T}^{2}$ & $\mathrm{~m} / \mathrm{s}^{2}$ \\
\hline$H$ & Height of specimen & $\mathrm{L}$ & $\mathrm{mm}$ \\
\hline$H_{0}$ & Initial height of specimen & $\mathrm{L}$ & $\mathrm{mm}$ \\
\hline$k$ & Intrinsic permeability & $L^{2}$ & $\mathrm{~m}^{2}$ \\
\hline$k_{\mathrm{i}}$ & In situ intrinsic permeability & $\mathrm{L}^{2}$ & $\mathrm{~m}^{2}$ \\
\hline K & Hydraulic conductivity & $\mathrm{L} / \mathrm{T}$ & $\mathrm{m} / \mathrm{s}$ \\
\hline$K_{\mathrm{i}}$ & In situ hydraulic conductivity & $\mathrm{L} / \mathrm{T}$ & $\mathrm{m} / \mathrm{s}$ \\
\hline$m_{v}$ & Coefficient of volume compressibility & $\mathrm{LT}^{2} / \mathrm{M}$ & $1 / \mathrm{kPa}$ \\
\hline$n$ & Porosity & Dimensionless & $\%$ \\
\hline OCR & Overconsolidation ratio & Dimensionless & \\
\hline$P_{c}^{\prime}$ & Maximum past effective normal stress & $\mathrm{M} / \mathrm{LT}^{2}$ & $\mathrm{MPa}$ \\
\hline SED & Strain energy density & $\mathrm{M} / \mathrm{LT}^{2}$ & $\mathrm{~kJ} / \mathrm{m}^{3}$ \\
\hline$u$ & Basal pore pressure & $\mathrm{M} / \mathrm{LT}^{2}$ & $\mathrm{kPa}$ \\
\hline$u_{\mathrm{b}}$ & Back pressure & $\mathrm{M} / \mathrm{LT}^{2}$ & $\mathrm{kPa}$ \\
\hline$\Delta u$ & Excess pore pressure & $\mathrm{M} / \mathrm{LT}^{2}$ & $\mathrm{kPa}$ \\
\hline$\delta_{\mathrm{n}}$ & Axial displacement & L & $\mathrm{mm}$ \\
\hline$\varepsilon$ & Axial strain & Dimensionless & $\%$ \\
\hline$\gamma_{w}$ & Unit weight of water & $\mathrm{M} / \mathrm{LT}^{2}$ & $\mathrm{kPa}$ \\
\hline$v$ & Dynamic fluid viscosity & M/LT & $\mathrm{Pa} \cdot \mathrm{s}$ \\
\hline$\rho$ & Fluid density & $\mathrm{M} / \mathrm{LT}^{2}$ & $\mathrm{~kg} / \mathrm{m}^{3}$ \\
\hline$\sigma_{v}$ & Applied vertical stress & $\mathrm{M} / \mathrm{LT}^{2}$ & $\mathrm{kPa}$ \\
\hline$\sigma_{v}^{\prime}$ & Vertical effective stress & $\mathrm{M} / \mathrm{LT}^{2}$ & $\mathrm{kPa}$ \\
\hline$\sigma_{\mathrm{vh}}^{\prime}$ & Hydrostatic vertical effective stress & $\mathrm{M} / \mathrm{LT}^{2}$ & $\mathrm{kPa}$ \\
\hline
\end{tabular}

